\title{
EL HOLLYWOOD DE CHANDLER: LA CONSTRUCCIÓN DE UN IMAGINARIO CINEMATOGRÁFICO EN CLAVE NOIR
}

\author{
CHANDLER'S HOLLYWOOD: THE CONSTRUCTION OF A \\ CINEMATOGRAPHIC IMAGINARY IN A NOIR KEY
}

\author{
JosÉ ISMAel GuTIÉRREZ \\ Universidad de Las Palmas de Gran Canaria \\ joseismael.gutierrez@ulpgc.es
}

Fecha de recepción: 05-11-2018

Fecha de aceptación: 07-06-2019

RESUMEN

La narrativa de Chandler, especialmente su novela The Little Sister, proporciona una visión distópica acerca de Hollywood durante el periodo de «sistema de estudios» de la industria cinematográfica norteamericana. Esta imagen desfavorable está en consonancia con los parámetros del género literario que cultivó el escritor: el género negro, que se caracteriza por el sórdido realismo, la presencia de villanos que rompen el orden establecido y la crítica social. La fusión de los códigos de esta modalidad narrativa que rezuma violencia con la ambigua actitud de Chandler ante la Meca del Cine daría como resultado la construcción de un universo criminal que revela muchos de los puntos débiles, ansiedades y conflictos de la colonia del cine hollywoodense.

PALABRAS ClAVE: Raymond Chandler; narrativa negra; narrativa de Hollywood.

\section{Abstract}

Chandler's narrative, especially his novel The Little Sister, provides a dystopian view of Hollywood during the period of the studio system in the American film industry. This 
unfavorable image is in line with the parameters of the literary genre that the writer cultivated: the noir gender, which is characterized by sordid realism, the presence of villains that break the established order and social criticism. The fusion of the codes of this narrative modality that oozes violence with the ambiguous attitude of Chandler before the Mecca of Cinema will result in the construction of a criminal universe that reveals many of the weaknesses, anxieties and conflicts of the film colony of Hollywood.

KEY WORDS: Raymond Chandler; noir narrative; Hollywood narrative.

\section{INTRODUCCIÓN}

En una carta fechada el 12 de enero de 1946, Raymond Chandler (1888-1959) se desahoga con su entonces editor Alfred Knopt:

[...] el panorama general es de una comunidad degradada, cuyo mismo idealismo es en gran medida falsificado. La presunción, el entusiasmo simulado, la bebida y el sexo constantes, las incesantes riñas por dinero, el agente entrometido, el pavoneo de los magnates (y su incompetencia casi siempre total para terminar cualquier cosa que empiezan), el miedo constante de perder todo ese oro y ser las nulidades que en realidad nunca dejaron de ser, las trampas mezquinas, todo ese condenado caos no es de este mundo (Chandler, 2013: 85-6).

En estas palabras se trasluce la desalentadora visión de Chandler acerca de un ámbito con el que trabó contacto durante un tiempo y ante el que siempre reaccionaría con más suspicacia que reverencia tanto antes como después de su participación como guionista para varios estudios de Hollywood.

El enfoque que da en sus ficciones al cine hollywoodense de la edad dorada parte de una premisa que desmitifica la ficción de magia y positividad que de esa industria de primer nivel forjaron sus pioneros en aras de un imaginario en el que dominan el crimen y las ambiciones perversas. Porque, para Chandler, Hollywood es un bochornoso campo propicio para el arraigo de falsedades y traiciones, para el drama, el exceso o la magnificencia, con individuos presuntuosos, paranoicos o de hábitos decadentes que caminan al filo del abismo, sin importarles el riesgo que corren.

Sobre las conexiones del escritor chicagüense con la Meca del Cine se han escrito ya bastantes páginas ${ }^{1}$. La Paramount Pictures reclamó en 1943 los servicios del novelista para la realización del guion de Double Indemnity (1944), la película de Billy Wilder basada en la novela de James M. Cain, colaborando a partir de ahí y de modo intermitente como es-

\footnotetext{
1 Véase, por ejemplo, Pendo (1976), Luhr (1991), Clark (1996), Phillips (2000) o MacShane (2017), que valoran el accidentado trabajo de Chandler como escritor de guiones, lo mismo que las adaptaciones de sus novelas a la gran pantalla.
} 
critor asalariado de la Universal y de la Warner Bros. ${ }^{2}$ Por otro lado, varios de los textos chandlerianos pasaron a la gran pantalla, aunque con desigual fortuna, entre 1942 y $1998^{3}$. Incluso un sector de la crítica ha llegado a catalogar su quinta novela, The Little Sister (1949), como una Hollywood novel en la que «el mundo del cine proporciona el opulento telón de fondo contra el que [el escritor] esgrime sus recuerdos llenos de reproches acerca de un mundo en el que nunca se sintió a gusto» (Clark, 1996: 154) ${ }^{4}$.

Que el escritor nunca se sintió parte integrante del universo de Hollywood es indiscutible, y esa sensación lo llevó a analizar con aspereza algunos de los engranajes que movilizan los ejes de la capital mundial del cinematógrafo de los años 30 y 40. Ese bloque temático de sus obras no se limita a The Little Sister, el texto de nuestro autor más rico en materia cinematográfica. Si bien en menor medida, tal foco interpretativo se expande hacia otras obras de más corto aliento en las que las intrigas que atañen a la «fábrica de sueños» o a algunos de sus espacios periféricos están más o menos latentes.

Al revisar todas sus aportaciones al fenómeno, caemos en la cuenta de que la perspectiva de Chandler sobre el imperio del cine americano levantado en el Medio Oeste apenas desafina con la mirada distópica que, desde la década de los 20, proyecta la llamada $\mathrm{Ho}$ llywood novel, o, como un apéndice o especie derivada de la misma, distintas novelas policiacas y de detectives — algunas de las cuales citaremos más adelante- que se adentran a fondo en las cloacas del séptimo arte.

Nuestro objetivo, el que nos trazamos en este artículo, no es otro, pues, que escudriñar la narrativa chandleriana a partir de las instancias y los mecanismos escriturales de esa distopía ficcional que el escritor amolda a los códigos de un género literariamente infravalorado hasta los años 70 con especial énfasis en «el realismo, la crítica social, el escenario urbano, el culto a la violencia», un género conformado en una prosa sin adornos, concisa y directa influenciada por el reportaje periodístico y, por supuesto, por el mismo cine, es decir, por los guiones que muchos de los escritores interceptados por Hollywood elaboraron para este emergente medio de comunicación de masas (Cerqueiro, 2010: 46-7).

${ }^{2}$ Fueron cinco los guiones que llegó a terminar, además del de Double Indemnity: And Now Tomorrow (1944), dirigida por Irving Pichel, a partir de la novela de Rachel Field (como coguionista figura también Frank Partos); The Unseen (1945), dirigida por Lewis Allen, a partir de la novela de Ethel Lina White (participó también en la escritura Hagan Wilde); The Blue Dahlia (1946), dirigida por George Marshall; Strangers on a Train (1951), dirigida por Alfred Hitchcock, a partir de la novela homónima de Patricia Highsmith (con un guion en el que intervinieron también Whitfield Cook, Czenzi Ormonde y Ben Hecht), y Playback, adaptación de su novela del mismo título y que nunca llegó a filmarse.

${ }^{3}$ Las novelas de Chandler han sido aclimatadas al cine en once ocasiones: Time to Kill (1942), dirigida por Herbert I. Leeds y basada en The High Window (1942); The Falcon Takes Over (1942), dirigida por Irving Reis y basada libremente en Farewell, My Lovely (1940); Murder, My Sweet (1944), dirigida por Edward Dmytrick y basada de nuevo en Farewell, My Lovely; The Big Sleep (1946), dirigida por Howard Hawks; Lady in the Lake (1947), dirigida por Robert Montgomery; The Brasher Doubloon (1947), dirigida por John Brahm y basada otra vez en The High Window; Marlowe (1969), dirigida por Paul Bogart y basada en The Little Sister; The Long Goodbye (1973), dirigida por Robert Altman; Farewell, My Lovely (1975), dirigida por Dick Richards; The Big Sleep (1978), dirigida por Michael Winner, y Poodle Springs (1998), dirigida por Bob Rafelson. A todas estas adaptaciones habría que sumar las diversas presencias de Marlowe en series televisivas de los años 50, 80 y 90.

${ }^{4}$ La traducción es nuestra. 


\section{LOS RENGLONES TORCIDOS DE LA «FÁBRICA DE SUEÑOS»}

El nexo que comunica la producción narrativa de Chandler con el cine hollywoodense se manifiesta en diversos grados de compromiso que revisten especial interés. Unas veces se traduce en una línea fabuladora que atraviesa gran parte de las tramas novelescas y los relatos del escritor, especialmente The Little Sister, que indaga en las oscuras condiciones de vida, en las luchas secretas y fracasos de los integrantes de la comunidad del celuloide, mientras que otras se resuelve con esporádicas incursiones que perfilan la idiosincrasia de algún personaje secundario o realzan el equívoco naturalismo de una acción. En The Lady in the Lake (1943) Birdie Keppel, peluquera y reportera de un periódico local de Puma Point, acompaña su afable saludo de presentación a Philip Marlowe con la siguiente apostilla: "Ya sé que es usted de Hollywood, la ciudad del pecado» (Chandler, 2012: 576). Semejante declaración no es baladí: se trata de un cliché que no debió de pillar desprevenido al escéptico detective californiano en tanto en cuanto resume la opinión que se tenía entonces de la colonia del cine instalada en el suroeste de los Estados Unidos 5 . Para el gran público, Hollywood era (y sigue siendo) un lugar de libertad desmedida, que vive de acuerdo con sus propias normas, poblado de clubes nocturnos, con una amplia oferta de actividades de ocio, sobre todo las vinculadas al sexo, las drogas o los juegos de azar. A los ojos de la sociedad de principios de los 40, la bajeza moral de la que alardean muchos actores y magnates, la desmesura en todos los sentidos (consumismo, fiebre hedonista, libertinaje sexual...), e incluso el robo a mano armada y el asesinato, encontraban un excelente caldo de cultivo en un Hollywood obstinado en amasar cuantiosas fortunas con la realización y venta de películas comerciales. Tanto es así que ese distrito, devorado por su propia factoría de mitos, acabará, a la postre, «viendo a los gánsters como personajes llenos de glamour en vez de simplemente como unos matones y extorsionistas» (Adler, 2008: 16). No olvidemos que, ya desde sus comienzos, los filmes de diez centavos producidos para los nickelodeons fueron censurados por los sectores más conservadores de la sociedad. Como recuerda Gabler, «[1]as grandes fortunas, las fortunas gentiles, consideraban con sospecha a las películas: económicamente, como una moda; moralmente, como vergüenzas potenciales» (2015: 132). En las primeras décadas del siglo $X X$, el cine aún no había alcanzado estatus de arte, siendo considerado una mera distracción al alcance de las clases trabajadoras; no una actividad digna del disfrute de los estratos medianos y altos de la sociedad.

Es cierto que ese aura de desenfreno, de perdición que circunda a todo lo proveniente de la industria del cine americano será compartido muy pronto por otros enclaves con idén-

\footnotetext{
${ }_{5}$ Por las mismas fechas, el narrador de I Hate Actors! (1944) de Ben Hecht observa que «[a]l leer los reportajes que publicaban los distintos periódicos, me daba perfecta cuenta de cómo había cambiado, no solo Hollywood, sino incluso el público. Donde se alzaba lo que una vez yo mismo había llamado "último refugio de los puritanos", triunfaba una alegre Saturnalia en la que se consentían todos los excesos. Los periodistas de la capital del cinema ofrecían constantemente al mundo relatos de las grandes pasiones de las estrellas. Los héroes y las heroínas predilectos del público aparecían danzando una especie de minueto sexual. El pecado era uno de los caminos más fáciles para conquistar la gloria, en lugar de ser uno de los medios más seguros de perderla. Y el público, que durante años había exigido de sus favoritos toda clase de virtudes, se divertía ahora al conocer su libertinaje» (1946: 82-3).
} 
tica mala fama, como Chicago o Las Vegas, que servirán también de acicate para que una multitud de novelas y películas de serie B hablase de la fragilidad que rodea a la vida y a las glorias mundanas. Los grandes hoteles con casinos empiezan a instaurarse en Las Vegas a partir de 1941, dos años antes de la publicación de The Lady in the Lake, y no pocos de los primeros inversores de esa urbe transformada en apenas diez años en epítome de la corrupción, de la inconsciencia derrochadora, del desmantelamiento de los valores tradicionales y del capitalismo más salvaje fueron acusados de haber llevado allí dinero sucio suministrado por los sindicatos del crimen de la costa Este $^{6}$.

Pero no será Las Vegas con sus carteles de luces de neón, sino el suroeste de Estados Unidos donde Marlowe, la principal creación salida de la pluma de Chandler, va a establecer su oficina a fines de los años 30 y por donde esparza su intenso aroma de cinismo. En relación con este emplazamiento, hay que decir que la estela de desasosiego que deja tras de sí a lo largo de su historia es antológica. La tendencia se fragua dos décadas antes, cuando el incipiente imperio cinematográfico se desplaza desde Nueva York a esta soleada región del territorio norteamericano y sus inmediaciones, donde se planificarán y realizarán películas legendarias que han encandilado a millones de espectadores de medio mundo. Allí es donde trabajarán, bajo leoninos contratos, las estrellas del celuloide durante la hegemonía del star system inventado por Zukor y Laemmle, y donde, además, muchas de ellas fijarán sus mansiones. Pero debido a la propensión de estas celebridades a dilapidar el dinero a mansalva, a fornicar más de lo que dictaban las normas de etiqueta o lejos de las circunstancias juzgadas como habituales, incluso a delinquir con tal de desbrozar el camino de posibles obstáculos que pudiesen interferir en su conquista del éxito, Los Ángeles —y en

${ }^{6}$ De hecho, el primer hotel de lujo de esta localidad del estado de Nevada (el Flamingo), en el que se rodará la versión original de Ocean's Eleven (1960), bajo las órdenes de Lewis Milestone, se edifica bajo la supervisión del gánster Benjamin «Bugsy» Siegel, sujeto con un amplio historial delictivo y en el que, por lo que se cuenta, está inspirado el turbio personaje de Sonny Steelgrave de The Little Sister (cfr. Moss, 2003: 167). En palabras de Adler, la construcción del Flamingo la orquestó Siegel «[c]omo un productor de Hollywood dispuesto a rodar un gran éxito de taquilla sin importarle el coste» (2008: 129). Hacia 1939 Siegel «ya estaba metido en la vida social de Los Ángeles» y aparecía regularmente en las crónicas de sociedad como un famoso más. Se convirtió en cliente habitual de los restaurantes de la colonia cinematográfica y salía con jóvenes estrellas; en casa de los magnates de los estudios organizaba partidas privadas de dados o acudía a otras residencias a jugar al póquer con diversos actores (Adler, 2008: 116). En Hollywood Siegel controlaba el sindicato de extras e ideó un astuto plan para extorsionar a los estudios de cine. Además, pedía dinero prestado a las celebridades, que nunca devolvía, sabiendo que no iban a reclamarle la deuda. Deseoso de entrar en Hollywood, llegó incluso a pagar para que le hicieran una prueba cinematográfica; sin embargo, su inmortalización en la gran pantalla solo llegaría cuatro décadas después de su muerte bajo el rostro de un actor popular: Warren Beatty, que dio vida al gánster neoyorquino en una película dirigida por Barry Levinson (Bugsy, 1991). No es ningún secreto la fascinación que Chandler, más allá de sus inquietudes como novelista, sintió por el mundo clandestino de la mafia. Tanto es así que no siempre echó la culpa a los miembros del hampa de todos los cargos que se les imputaron. En el gánster «Lucky» Luciano, juzgado, encarcelado y más tarde deportado, quiso ver un simple chivo expiatorio. A raíz de un encuentro con él en la primavera de 1958 en un hotel de Nápoles, escribió un artículo para The Sunday Times que nunca vio la luz por miedo a represalias legales (Chandler, 2013: 438-42). Luciano era conocido por suministrar a los artistas de cine cocaína y heroína; de hecho, controló el negocio de la droga, del juego y la prostitución en Los Ángeles. Además, tuvo un lance amoroso con la actriz Thelma Todd, que murió a los treinta años en extrañas circunstancias. 
particular Hollywood - terminará fundiéndose a conceptos como «pecador», «disoluto», «obsceno», «inmoral», «corrupto», etc.

Esta mala prensa que va granjeándose el negocio del cine made in USA es reforzada por las innumerables relaciones que Hollywood, de un modo u otro, ha establecido con la mafia, dos mundos entre los que Tim Adler ha advertido oportunas concomitancias: idénticos intereses, idénticos métodos de actuación, incluso similares orígenes: «Tanto Hollywood como el crimen organizado ofrecen a la gente lo que quiere. Uno vende escapismo a través de imágenes parpadeantes, mientras que el otro vende evasión mediante las drogas, el sexo y el juego» (2008: 15).

Hollywood y el hampa han convivido como hermanos siameses atados por un cordón umbilical que les ha permitido retroalimentarse recíprocamente. Los magnates de la «Edad de Oro» del cine se comportaban como gánsteres: eran agresivos, malhablados y adoptaban actitudes intimidatorias. Varias actrices y aspirantes a estrellas, lo mismo que la Mavis Weld de The Little Sister, eran sorprendidas intimando con miembros de la mafia o se fotografiaban con ellos. Entre el círculo de amistades de algunos de los representantes del hampa se encontraban actores como George Raft, Errol Flynn, Judy Garland, Jean Harlow, Robert Mitchum, Lana Turner o Ava Gardner, entre otros, o productores y ejecutivos de los grandes estudios como Harry Cohn, Louis B. Mayer y Jack Warner. En ocasiones malhechores de postín y figuras de la interpretación vivían puerta con puerta o acudían de la mano a los mismos clubes y restaurantes de moda ${ }^{7}$.

Otro de los vasos comunicantes que enlaza a Hollywood con los contextos marginales del gansterismo reside en que ambos segmentos son, en cierta medida, sociedades secretas cuyos exponentes raramente hablan con forasteros. Cecilia Brady, la narradora de The Last Tycoon (1941) de F. Scott Fitzgerald, hija de una poderosa familia de Hollywood, lo deja bien claro:

En Hollywood no solemos relacionarnos con desconocidos, a menos que lleven un letrero que indique que han dejado el hacha en otro lugar, y que en cualquier caso no va a caer sobre nuestros pescuezos, es decir, a menos que sean una celebridad. Incluso en ese supuesto caso, más vale andarse con cuidado (Fitzgerald, 2014: 28-9).

De ahí que la apreciación de la periodista amateur Birdie Keppel en The Lady in the Lake que reproducimos más arriba apenas objetive una creencia con fundamento en la realidad cotidiana.

${ }^{7}$ Entre esos locales a los que era asidua la gente de la farándula de esa época destacan el Musso's, el Victor's, el Trocadero, el Ciro’s, el Mocambo o el Romanoff's. El capo de la mafia chicagüense Sam Giancana le contó a su hermano Chuck que, entre las estrellas a las que la Organización había ayudado en sus carreras — «Organización» es el nombre que recibían en Chicago los grupos del crimen organizado- estaban los Hermanos Marx, Frank Sinatra, Gary Grant o Gary Cooper (Adler, 2008: 132). Giancana, que no ocultó su desafección hacia el espectáculo cinematográfico, comentó también en otra ocasión que «lo único en lo que eran buenas las estrellas de Hollywood era haciendo de "correo", transportando dinero por todo el país» (Adler, 2008: 134). El público estaba tan deslumbrado por los astros del celuloide, a los que asediaban pidiéndoles autógrafos, que jamás se preguntaba qué llevaban guardado en el maletín. 
«Puedes vivir en Hollywood un montón de tiempo sin llegar a ver nunca lo que hay detrás de las películas» (Chandler, 2012: 791); es una de las muchas descalificaciones que la narrativa de Chandler arroja contra la industria del cine. Con ella se cuestiona, junto a la falta de escrúpulos imperante en ese negocio, la hipocresía general y el secretismo de sus operaciones financieras o de sus proyectos cinematográficos. Aclaremos, sin embargo, que no siempre esta ciudad en la que ven la luz tantas películas al año ha estado impregnada de la malsana infamia que suelen atribuirle sus detractores y que los textos chandlerianos, a instancia de las investigaciones de su protagonista o a partir de los distintos incidentes que se desencadenan, parecen corroborar. En The Little Sister, un Marlowe nostálgico contrapone la bucólica estampa, ya extinta, del actual Olimpo de las estrellas a la imagen adulterada que mostraba en aquellos días de finales de los 40:

Había árboles por todo el Bulevar Wilshire. Beverly Hills era un pueblecito, Westwood estaba sin urbanizar y se vendían parcelas a mil cien dólares, pero nadie los compraba. Hollywood era un conjunto de barracas en la línea interurbana. Los Ángeles era solo un sitio grande, seco y soleado, con casas feas y sin estilo, pero con gente amable y pacífica. Tenía el clima del que ahora tanto presumen. La gente dormía al aire libre, en los porches de las casas. Había grupos de seudointelectuales que la llamaban la Atenas de América. No lo era, pero tampoco era un basurero con letreros de neón, como es ahora (Chandler, 2012: 848).

Con la llegada de la industrialización, del auge económico, ese bucolismo rústico y aburrido se va al traste, ocupando su lugar una imparable corriente mercantilista que potencia, como mínimo, la emergencia del artificio, de la permisividad, de la diversión y una pérdida de estilo arquitectónico o de vida propio, aunque modesto, cuya autenticidad tosca y rutinaria cae en picado al calor de las múltiples fechorías que se comenten. El empobrecimiento moral y la postiza honorabilidad de la que se jactan los nuevos ricos - muchos de ellos dedicados a la delincuencia - marchan codo con codo, fulminando así la ancestral identidad de Los Ángeles en tanto que espacio arcádico de la Norteamérica tradicional. Tras la irrupción del vil metal, el crimen inunda las calles y comercios; la ciudad se tornará entonces un sitio cada vez más inseguro, infectado de granujas y de rastacueros con pretensiones suntuosas y aristocráticas, cuando no de gente sexualmente perversa, categoría esta última en la que se incluirían no solo cualquier hombre o mujer con inclinaciones promiscuas, sino las profesionales del sexo, por no hablar de los homosexuales, ya que, según el punto de vista homofóbico de la época, que el mismo Chandler compartía, los gais y las lesbianas son sujetos viciosos, enfermos, e incluso delincuentes:

- Ahora tenemos personajes como este Steelgrave que son dueños de restaurantes. Tenemos tipos como ese gordo que me chilló antes. Hay dinero a espuertas, pistoleros, comisionistas, chicos en busca de dinero fácil, maleantes de Nueva York, Chicago y Detroit... y hasta de Cleveland. Esa gente es dueña de los restaurantes de moda, de los clubes nocturnos, de los hoteles y de las

${ }^{8}$ Frecuentemente la ciudad de Los Ángeles de principios del siglo XX, donde se enclavaba el suburbio de Hollywood, es recordada como «un pueblecillo primitivo cuyas carreteras pavimentadas acababan de repente en el centro y cuya arquitectura principal eran pequeñas chabolas rodeadas de naranjos y pimenteros» (Gabler, 2015: 192). 
casas de apartamentos. $Y$ en esas casas vive toda clase de timadores, bandidos y aventureras. Putas de superlujo, decoradores mariquitas, diseñadoras lesbianas, toda la chusma de una ciudad grande y despiadada, con menos personalidad que un vaso de papel. En las urbanizaciones elegantes, el querido papá lee la crónica de deportes delante de un ventanal, con los zapatos quitados, convencido de que es un tío con clase porque posee un garaje para tres coches. Mamá está delante de su tocador de princesa, intentando disimular con maquillaje las bolsas que tiene debajo de los ojos. Y el hijo del alma está pegado al teléfono llamando a una serie de colegialas que no saben hablar, pero que llevan la polvera llena de preservativos (Chandler, 2012: 848-49).

De no ser por la envidiable labor dinamizadora que implementa la maquinaria bien engrasada del cine gracias al esfuerzo de una serie de hombres emprendedores - la mayoría inmigrantes judíos procedentes de Europa central u oriental- y que otorga un plus de relativo cosmopolitismo a los andurriales pecaminosos de Los Ángeles, la urbe al completo, esa «ciudad grande y despiadada», con sus letreros luminiscentes, sus tiendas y restaurantes, sus prostíbulos y casas de juego, no sería más que un soez cortijo sin señas identitarias dignas de mención:

- Las ciudades auténticas tienen otra cosa, una especie de estructura ósea individual debajo de toda la porquería. Los Ángeles tiene a Hollywood... y lo detesta. Debería darse con un canto en los dientes. Si no fuera por Hollywood, esta ciudad sería como un catálogo de venta por correo. Todo lo que hay en el catálogo se puede encontrar en otro sitio, solo que mejor (Chandler, 2012: 849).

Llama la atención que este sea uno de los pocos razonamientos medianamente favorables que hallamos en las obras de Chandler sobre Hollywood. Porque, si es verdad que la prosperidad de Los Ángeles estriba en parte en la inyección de divisas que aporta el cine y que otras zonas geográficas, como señalábamos al principio, acabarán erigiéndose en emporios del raqueterismo urbano, del despilfarro pecuniario y de las riquezas a la deriva, un sector de la producción cinematográfica hollywoodense, así como la literatura interesada en ella o las crónicas históricas escritas por autores como Kenneth Anger — Hollywood Babylon (1956, 1984) — o en España Rafael Dalmau Parés — Hollywood: entre Sodoma y Babilonia (2005) —, no dan puntada sin hilo en sus tentativas por desmontar la quintaesencia del sueño que propalan los responsables de la industria cinematográfica desde la era del cine mudo.

Más bien se aprecia la tendencia opuesta, es decir, coqueteando con el reportaje periodístico de signo amarillista, esa mítica fábrica de opulencia es enfocada como un viciado microcosmos en el que todo es de segundo orden, donde se hacina una multitud de sujetos egocéntricos, cocainómanos, falsarios, sexoadictos, cobardes y egoístas, aunque se les quiera disfrazar con una máscara de aspecto glamuroso.

La existencia de esta jungla impúdica y descontrolada se constata desde la génesis de la aventura del celuloide. Incluso, antes de que la mafia pusiese sus ojos en Hollywood, los estudios ya estaban inmersos en actividades opacas. Adler recuerda que la «MGM tenía su propio prostíbulo al norte de Sunset Strip, dirigido por la actriz Billie Bennet», donde se atendía sobre todo «a managers de cine y a miembros de equipos extranjeros que venían de 
visita. Las prostitutas eran dobles de estrellas famosas de cine» (2008: 69). De otro lado, los gerifaltes de las compañías cinematográficas tenían ya tratos con el mundo del crimen organizado: «Frank Orsatti, la mano derecha del jefe de la MGM Louis B. Mayer, era un contrabandista y un gánster» (Adler, 2008: 69).

Verdaderamente no pueden florecer síntomas de autenticidad en estos círculos de «amistades peligrosas», víctimas o artífices de ominosas tragedias y depravaciones, cuyo número no hará sino incrementarse con el paso de los años. Esta va a ser la tónica dominante durante el periodo en el que nos centramos y lo que constituya la materia prima de la que se nutre la novela policiaca. Como era de esperar, este clima de tolerancia acabará desatando la ira de las ligas católicas contra la inmoralidad, las cuales aspiran a frenar toda esa marejada de descarríos que dañaba el impoluto rostro de la decencia y de las buenas costumbres por las que se distinguía, supuestamente, la sociedad biempensante de los Estados Unidos. El resultado para el arte cinematográfico será la aprobación del «código Hays» en 1930, por sugerencia del Studio Relations Committee (SRC) ${ }^{9}$. Una política de censura que, fuera de la pantalla, no siempre tuvo los efectos que perseguía, ya que Cinelandia siempre tuvo habilidad para conservar intacto un espacio en el que poder dar rienda suelta a sus hábitos relajados, desatendiendo los alegatos en contra del escándalo, la incorrección y la promiscuidad carnal o de cualquier otro tipo de que era objeto.

Así, mientras la imagen fílmica contribuía a inculcar a la sociedad estadounidense y al resto del mundo una ficción nacional basada en el American dream o en el American way of life, transmisor de una mezcla de entusiasmo individualista y de principios conservadores, la novela negra, con su violencia policial y su ácida crítica a distintos estamentos sociales, desde los más marginales hasta los más elitistas, se especializa en voltear la moneda para sacar a relucir la cara más devastadora que se esconde tras la quimera del cine. Sin la transgresión de la ley y de las convenciones establecidas, sin homicidios que acaparen las portadas de los diarios, sin atracos a entidades bancarias o robos a casas particulares o sin los chantajes de los que son víctimas las luminarias del celuloide o personajes de importancia menor, es decir, sin la visibilización de la codicia y de la lucha por la propiedad privada o la riqueza, no existiría el género. Y no es casual que esta quiebra de la paz en la apaciguada vida colectiva que pondría en un brete a la jerarquía social y familiar de la Norteamérica timorata que representaban los prósperos empresarios judíos elija a Hollywood como vector de sucesos en los que compiten entre sí lo sublime y lo inmundo, lo alto y lo bajo, lo grandioso y lo insignificante, la vanidad y el talento.

Según especifica Chandler en The Simple Art of Murder (1950), la vertiente realista de la novela policiaca informa regularmente sobre un conflicto «en el que un astro cinematográfico puede ser el confidente de una pandilla» (1996: 76) ${ }^{10}$. Así, Alex Morny, personaje

9 En 1930 se crea dicho comité encargado de aplicar unas normas estrictas escritas por William H. Hays en 1927 que contenía aquellos temas que, en su opinión, deberían evitarse en las producciones cinematográficas. Como dicho organismo no tenía autoridad real para aplicar esas medidas, muchas películas siguen saltándoselas, hasta que en 1934, tras la fundación de la Legión de la Decencia, se hace una enmienda al código que dictaba que todas las películas debían obtener un certificado antes de su estreno.

${ }^{10}$ La traducción es nuestra. 
secundario de The High Window (1942), había renunciado a una carrera mediocre como actor de cine para consagrarse a negocios de dudosa respetabilidad, pero con los que obtiene mayores ganancias, como la dirección de un club nocturno y de una casa de juegos. Un tipo con aires de mafioso del que no hay que fiarse, al decir de los que lo han tratado. Al enfrentarse Marlowe cara a cara con él, refiere que: «Recordaba haberlo visto en las películas hacía mucho tiempo, por lo menos diez años atrás. No me acordaba de en qué películas, ni de qué trataban ni qué era lo que hacía él en ellas, pero me acordaba de aquella cara morena y sólida con la cicatriz arrugada. Por aquel entonces, su pelo era oscuro» (Chandler, 2012: 455). De esta forma se bosqueja narrativamente el retrato de un personaje inventado pero con ínfulas de verosimilitud, pues, en efecto, en un medio con tantos reveses y cambios de rumbo como los que se experimenta en Hollywood, hubo actores que, aburridos cuando el éxito se les resistía, optaron por abandonar esa profesión para dedicarse a quehaceres más clandestinos, o a la inversa, es decir, matones que procuraban hacerse con un lugar en el tentador negocio del cine, ya sea como intérpretes, como productores o como agentes artísticos. En enclaves de esta categoría el mal germina como una planta invasora que, por mucho que se la pode, sigue creciendo y reproduciéndose sin parar. En The Little Sister, a la alarma de una de las clientas, temerosa de que unos gánsteres de Bay City hubiesen cercenado la vida de un hermano suyo, el detective le replica impasible y con su peculiar estilo irónico que esa posibilidad la encuentra remota, puesto que todos los gánsteres que él conoce trabajan en el cine (Chandler, 2012: 812).

El cine es, entonces, el sanctasanctórum en el que convergen los prolíficos trapicheos a los que se entrega con liberalidad un ejército de mujeres y hombres de cuestionable reputación. Comúnmente los propietarios y trabajadores de los estudios confraternizan con personajes del hampa, pero también los criminales disfrutan codeándose con la gente famosa. Las películas, señala Adler, enseñaron a los gánsteres cómo vestirse, cómo hablar y gesticular (2008: 16). El formato policial, se cimente o no en casos inspirados en la realidad de sobornos, latrocinios o asesinatos, prácticas que vulneran las normas instauradas de la convivencia ciudadana, es consustancial tanto a la modalidad de la «novela-problema» o «novela-enigma» como al relato escrito según el patrón hard-boiled. Una y otra variante simulan un híbrido que conjuga lo mejor de dos géneros escriturales exitosos: la literatura de detectives, por un lado, y otra categoría típicamente americana, aunque con proyecciones en otras nacionalidades, que se conoce como Hollywood novel ${ }^{11}$. Considerada por Edington (1995: 64) y Christensen (2014: 2) como articulaciones ficcionales del ocaso del «sueño americano», la Hollywood novel tematiza, desde distintos ángulos, las vicisitudes del cine y de sus potentados, la beligerancia de los guionistas por ejercer libremente su trabajo y que se les reconozca en su justa medida, el ascenso y la decadencia de las estrellas de la pantalla o las frustraciones de los extras, con pesimistas reflexiones sobre la mercantilización del arte cinematográfico o sombríos estudios acerca de la patologización del deseo. Nacida en la etapa del cine mudo durante los años 1910, la Hollywood narrative se prolonga a lo largo del fructífero periodo del studio system — un modelo estructural que favorecerá la aparición

11 Nosotros preferimos la expresión Hollywood narrative, ya que permitiría englobar a narraciones cortas sobre la misma temática. 
de la edad de oro del cine hollywoodense- fundando una tradición cuyas secuelas residuales, un tanto depauperadas, sobreviven como revivals hasta nuestros días. En sus mejores productos y por mucho tiempo, esa literatura propende a la disección de las putrefactas vísceras de la comunidad fílmica americana y, muy en particular, la que se desarrolla en las décadas de los 30, 40 y 50, que es el periodo creativamente más refulgente de Hollywood ${ }^{12}$.

Junto a este corpus de narraciones de asunto hollywoodense, otro papel sobresaliente desempeñado por otros circuitos de difusión masiva, paralelos al libro impreso y que entroncan con la embrionaria estética «dura» de la literatura noir, corresponde a las revistas pulp, una parte de las cuales se ven animadas por detectives que ejercen en espacios hollywoodenses o cercanos a él, como el Dan Turner de Robert Leslie Bellem, el más conocido de todos, que despunta en 1934 en las modestas páginas de Spicy Detective Stories (magacín más tarde rebautizado con el nombre de Speed Detective), aunque sus delirantes aventuras seguirán haciendo las delicias del lector entre 1942 y 1943 en Dan Turner-Hollywood Detective y, con menor frecuencia, en Private Detective Stories. La aceptación masiva de este sabueso con espíritu de donjuán pendenciero es tal que, más o menos por la misma época, hará su aparición la revista Hollywood Detective (1934-1950), que dará hospedaje a relatos del propio Bellem, firmados con su verdadero nombre o bajo seudónimos, y de otros muchos autores: Ellery Waltson Calder, Harley L. Court, Anon, Robert A. Garron (seudónimo de Howard E. Wandrei), Laurence Donovan, Harold de Poco, E. Hoffmann Price (sobrenombre de Hamlin Daly) y un largo etcétera.

En 1950, coincidiendo con la desaparición de Hollywood Detective y el languidecimiento del resto de publicaciones pulp, la mencionada revista pasaría a llamarse Hollywood Detective Magazine, y en ella van a colaborar desde Beresford King hasta Rhett Rutledge, pasando por Leonard Finley Hilts o Ladson Church o el mismo Bellem, que ofrecerá nuevas y jugosas entregas de la serie liderada por su famoso tough eye Dan Turner. De esta manera, incontables investigadores privados de distinto pelaje e idiosincrasia salen a destajo de las máquinas de escribir de los maestros de la literatura policiaca y de muchos autores menores, como Bellem o los arriba enumerados, todos definidos por un mismo carácter rudo y sarcástico, una misma adicción al alcohol y a la lascivia y una inveterada alergia al sedentarismo y a la comodidad a la que incita el capitalismo burgués.

12 Pese a que la obra que instaura, dentro del modelo detectivesco, este paradigma sea tal vez The Film Mystery (1921) de Arthur B. Reeve, son tantos los títulos publicados durante esos y los siguientes decenios que resulta imposible abarcarlos todos con una sola mirada. Aun así, baste mencionar, entre otros, The Hollywood Murder Mystery (1930) de Herbert Crooker, A Roman Holiday (1930) de Don Ryan, Death in a Bowl (1931) de Raoul Whitfield, The Death Kiss (1932) de Madelon St. Dennis, Murder in Hollywood (1936), de Cromwell Gibbons, The Case of the Baker Street Irregulars (1940) de Anthony Boucher, I Wake Up Screaming (1941) de Steve Fisher, Lazarus \# 7 (1942) de Richard Sale —un eficaz entretenimiento que en su día sorprendió por su alto contenido sexual—, I Hate Actors! de Ben Hecht, In a Lonely Place (1947) de Dorothy B. Hughes —llevada al cine en 1950 por Nicholas Ray- o The Devil to Pay (1938), The Four of Hearts (1938) y The Origin of Evil (1951) de Ellery Queen. 


\section{CHANDLER FRENTE A HOLLYWOOD}

Sin ser cronológicamente el primer autor, uno de los máximos exponentes del género negro que se relaciona, muy a su pesar, con Hollywood es Chandler. Como hemos adelantado más arriba, su novela The Little Sister, producida a finales de los 40, es calificada por algunos como una Hollywood novel, aun cuando en algunas otras el escritor chicagüense disemine también unas cuantas referencias explícitas a profesionales del cine y a problemas generados en ese enclave. Es más, en Poodle Springs, la obra que dejó incompleta al morir y que terminó en 1989 Robert B. Parker, sigue apareciendo en segundo plano el cine de Hollywood. Ello no ha de extrañar: debilidades humanas, como la rabia, las ansias de poder, la envidia, el odio o la avaricia, sobre las que pivota el acontecimiento criminológico que radiografía la narrativa detectivesca chandleriana, encuentran en esa plataforma un núcleo humano favorable para la eclosión de pasiones demoledoras. Chip Rhodes, que ha examinado en profundidad The Little Sister desde una óptica freudiana, opina que

utiliza el conflicto temático entre el arte y el deseo para generar un diagnóstico de la cultura nacional bajo la era de los estudios que rivaliza al Oeste por su pesimismo debido a los efectos del deseo frustrado. Aun así, Chandler conserva una fuerte fe en la estética del Romanticismo americano. Se considera generalmente una de las novelas más flojas de Chandler porque su preocupación por la industria cinematográfica es tan iracunda que influye en la visión que nos da de ella (2008: 12) $)^{13}$.

Al lado de Whitfield, Bellem, McCoy, Fisher, Sale, Hughes o MacDonald, Chandler se erige como uno de los autores que consolidó un imaginario narrativo que, aunque solo sea esporádicamente, perfora el lado menos gratificante, menos ensoñador del Hollywood de las décadas de los 30 y 40, tan decisivas para el desarrollo y el futuro mediático del cine como arte y como industria. Mucho antes que en The Little Sister y antes de empezar a trabajar en Hollywood, en sus ficciones breves, publicadas más o menos durante el mismo paréntesis temporal que las de Bellem (entre 1933 y 1939, concretamente) en las revistas Dime Detective, Detective Fiction Weekly y Black Mask, el rey de los pulps de crimen y misterio, desentumece ya una variedad de oscuros disturbios en los que se involucran distintos elementos de la ciudad de Los Ángeles y de otros lugares enclavados en los suburbios de la Meca del Cine, donde los fraudes, las extorsiones y los asesinatos a astros de la pantalla o a otros personajes adyacentes vinculados, directa o indirectamente, con la producción de películas están a la orden del día.

En cuanto se afianza como principal plató a escala nacional a principios del siglo pasado - momento en que se levantan los primeros sets de rodaje-, Hollywood se consolida como una entusiasta fábrica de hacer dinero, afanada en materializar fantasías y mitos populares que sobredimensionan, a través de la obstinada política publicitaria de los estudios, la ingenua imaginación de un público con la suficiente hambre de entretenimiento como para consentir gastar parte de sus ganancias y su tiempo libre en este arte de masas. La finalidad de los empresarios del ramo no es otra que asegurarse una posición lo más ele-

\footnotetext{
${ }^{13}$ La traducción es nuestra.
} 
vada posible en ese medio que se sustenta en la inmortalización de chispeantes imágenes en movimiento que, a la vez que cuentan una historia, imponen modas y estilos y divulgan una ideología. Dada la importancia que tienen las apariencias, se comprende también que a nadie con cierta implicación en la factoría del cine habría de complacerle la posible catástrofe material ocasionada por la mala publicidad de las estrellas, de los directores o de los mismos responsables de las compañías cinematográficas; de ahí que los famosos, inquietos por cualquier escándalo que pudiese desprestigiarlos, resulten presa fácil, no ya solo para los periodistas de chismorreos, sino para los amantes del vil metal. El chantaje es uno de los señuelos más utilizados para ponerlos en apuros, de modo que, con vistas a preservar el velo de impecable misterio que los recubre, sus carismáticos destellos de oropeles y su leyenda, deben hacerse ciertas concesiones. Ocultar los trapos sucios de los intérpretes debajo de la alfombra para salvaguardar ese espejismo se convierte en una obsesión repetitiva. El miedo a que una extorsión pudiera destruir la carrera de un actor parece justificar las medidas a adoptar: «Nada de pasta gansa, nada de piscinas con luces bajo el agua, nada de visones plateados, nada de anuncios de neón con su nombre. Todo volaría como puro polvo», pronostica Marlowe en The Little Sister (Chandler, 2012: 797), a la vez que medita sobre el modo en que personas sin una pizca de talento pueden llegar a lo más alto y alzarse en iconos de la gran pantalla, pero también sobre la facilidad con que sujetos normales y vulgares son susceptibles de envilecerse cuando la ambición los aguijonea.

«Blackmailers Don't Shoot» ${ }^{14}$, uno de los primeros cuentos chandlerianos, despliega una enrevesada fábula que tiene como epicentro a Rhonda Farr, una actriz a la que presionan con unas cartas personales que, de hacerse públicas, podrían fin a su profesión. El mismo recurso lo explota Bellem por la misma época. En este caso el problema no se reduce a una simple amenaza verbal ante la que podría ceder o no: la joven será víctima también de un secuestro para, luego, mediante un rescate express, ser liberada. Todo se resuelve satisfactoriamente gracias a la inestimable colaboración del detective Mallory, un personaje contemporáneo de Race Williams, Sam Spade, Dan Turner y muchos otros. A juzgar por las palabras de este sabueso, interferencias de esta naturaleza debían de ser muy comunes en el Hollywood de esos años. Baste pensar que, tal y como relata Mallory, un importante estudio lo lleva tentando para que acepte una oferta de trabajo, sin especificar cuáles serían exactamente sus obligaciones, aunque podemos adivinarlo ${ }^{15}$.

Que los estudios disponían de personal asalariado que velaba por la seguridad de los trabajadores, así como por el buen nombre de los directivos y la discreción con la que debían ejecutarse sus proyectos, lo atestigua otro cuento imbuido de reminiscencias temáticas fílmicas: «Smart-Aleck Kill» ${ }^{16}$, donde Johnny Dalmas, investigador protagonista de varias historias cortas de Chandler, se desenvuelve en sectores cercanos a Hollywood, aunque no

14 Publicado en Black Mask (diciembre, 1933).

15 El Toby Peters de Stuart M. Kaminsky, nacido literariamente varias décadas después, pero que también se dedica a fisgonear en los basureros de la gente rica o marginal del área metropolitana próxima al cine durante la década de los 40, actuó durante unos meses como «gorila» para la Warner Brothers hasta que lo despidieron por haber agredido a una estrella de películas del Oeste

16 Publicado en Black Mask (julio, 1934). Otras empresas que recurrían a detectives eran las ligadas al ramo de la hostelería. En varios relatos y novelas de Hammett, Chandler y MacDonald, así como en la narrativa de 
se le vea trabajando para ningún estudio en concreto. En esta historia Dalmas halla en su domicilio sin vida, con una bala en la sien, al director de cine porno Derek Walden, quien había contactado con él para pedirle que desbaratase el malévolo plan que contra su persona estaba urdiendo una organización de delincuentes interesados en sacarle dinero a cualquier precio $^{17}$. Chantajeada también resulta Mavis Weld en The Little Sister por una instantánea en la que se la ve junto a un exgánster de Cleveland de la que la actriz estaba prendada por aquella época. Esta foto, que el mismo hermano de la actriz le había tomado en un club en una fecha en que supuestamente su acompañante masculino debía estar en la cárcel, podría desmontar, de caer en manos de la policía, la coartada que lo exculpaba del asesinato de un tal Sunny Moe Stein.

Aunque Chandler no consideró haber escrito jamás una Hollywood novel propiamente dicha, empresa para la que se requería de una memoria más fotográfica que la suya, según admite en una carta a Edward Week (Chandler, 2013: 310) ${ }^{18}$, lo cierto es que, entre sus novelas, The Little Sister es la más generosa en cuanto a incursiones al mundo del cine y a sus problemas se refiere. Por ejemplo, en las oficinas de los magnates hacen largas colas durante horas actores en busca de un contrato para intervenir en un filme, como es el caso de Billy Fortescue, quien, desesperado por la larga espera, entra en cólera delante de la señorita Helen Grady, la secretaria de Sherry Ballou ${ }^{19}$.

En esta novela se reflexiona también sobre el papel de la ficción en el consumidor. Las películas, observa Ballou, apelan a la parte más emocional del público sumiéndolo en la ilusión de que los dramas proyectados en la pantalla son reales o, al menos, probables:

Si uno ve en la pantalla a una estrella guapísima en una situación de grave peligro, teme por ella con una parte de la mente, la parte emocional. Y eso a pesar de que la mente racional sabe que, siendo la estrella de la película, no puede ocurrir nada muy malo. Si el suspense y la amenaza no fueran más fuertes que la razón, el drama no tendría mucho futuro (Chandler, 2012: 796).

\footnotetext{
Kaminsky y de otros autores norteamericanos o extranjeros que sitúan la acción de sus obras en Estados Unidos encontramos detectives que prestan o han prestado sus servicios en hoteles.

${ }^{17}$ De tomar al pie de la letra lo que cuenta el relato, ya por esa época debía haber en Hollywood una incipiente industria de cine porno que operaba al margen de los circuitos del cine comercial, presumiblemente financiada por la mafia. Recordemos que en la novela de Horace McCoy I Should Have Stayed Home (1938) una insaciable señora Smithers le propone a un todavía inexperto Ralph Carston ver una película porno en su habitación. De ahí que los orígenes de la historia marginal de ese «otro Hollywood» que nos cuentan McNeil y Osborne (2008) y que arranca en la década de los 50, deberían retrotraerse al menos una veintena de años.

${ }^{18}$ Esta carta está fechada el 27 de febrero de 1957.

${ }_{19}$ Con una escena parecida, pero sin pizca de violencia, se encuentra el detective Lew Archer en The Moving Target (1949), de Ross MacDonald. Aquí la cola la forma «una docena de personas sentadas en sillas con respaldos en la antesala de la oficina de selección; [que] intentaban parecer muy solicitados y satisfechos de sí mismos. Una joven vestida con un pulcro traje negro desgastado se quitaba y se ponía los guantes. Una mujer con el ceño fruncido tenía sentada en sus rodillas a una niña con el ceño fruncido, vestida de seda rosa y gimoteando. El habitual surtido de actores marginados — gordos, delgados, barbudos, afeitados, vestidos de etiqueta, con sombreros, enfermos, alcohólicos y seniles - se encontraba allí sentado muy dignamente, esperando para nada» (MacDonald, 2010: 45).
} 
En ese «pacto ficcional» se fortalece la necesaria mentira que preserva un efecto encantatorio en la expectante mente del espectador, dispuesto a abstraerse, mientras dure el espectáculo cinematográfico, de sus problemas cotidianos, que sí son reales.

En The Little Sister los pasos del detective lo llevan, en busca de respuestas, a los cenáculos del cine, donde los actores son pura fachada, bellos por fuera y feos o vacuos por dentro, donde actrices se ennovian con mafiosos porque lo consideran chic y porque tienen recursos suficientes como para satisfacer todos sus caprichos, donde las rivalidades entre colegas resultan vergonzosas. El detective repara en el poder de Hollywood para transformar externa e internamente a las personas más inocentes hasta trastocarlas y volverlas irreconocibles:

Es asombroso lo que puede hacer Hollywood con un don nadie. Es capaz de convertir en una deslumbrante vampiresa a una vulgar mujerzuela que solo sirve para plancharle las camisas a un camionero. Un mozalbete hiperdesarrollado, que parecía destinado a acudir todos los días al tajo con la tartera, se transforma en un héroe varonil, de mirada radiante y sonrisa resplandeciente. Una camarera de Texas, con la cultura de un personaje de historieta, se convierte en una cortesana de fama mundial, casada seis veces con seis millonarios, y acaba tan hastiada y decadente que lo único que le parece emocionante es seducir a un mozo de cuerda con la camisa bien sudada.

$Y$ por control remoto, es incluso capaz de coger a un pobre paleto sinvergüenza como Orrin Quest y convertirlo en cuestión de meses en el asesino del picahielos, elevando su mal carácter natural al nivel del sadismo clásico de asesino en serie (Chandler, 2012: 828-29).

Marlowe se las tiene que ver con ejemplares de este calibre, demasiado humanos $-\mathrm{y}$, por lo tanto, imperfectos - en sus vicios y espíritu de conformismo que apenas despiertan admiración, pero en su peregrinaje ordinario también se cruza con míseros aspirantes a la buena vida cuyas mediocres existencias sucumben bajo los carteles que anuncian prometedoramente el engañoso mensaje «Bienvenidos al Sueño Americano». Mientras se desenvuelve entre unos y otros, sin integrarse en ningún bando, procura que el lodo que fluye a raudales en torno a él no acabe salpicándolo. Esto lo obliga a asumir un distanciamiento, del que tanto precisa para deconstruir analíticamente el caótico microcosmos de Los Ángeles, lo que propicia, por ejemplo, uno de los más audaces juicios sobre las finanzas hollywoodenses que uno haya leído nunca en una novela negra. En un momento dado, Jules Oppenheimer, dueño de 1.500 cines y de unos estudios cinematográficos poderosos, le ofrece a Marlowe un puro, que él rechaza porque ya tenía encendido un cigarrillo. En vez de devolver el puro al estuche, el magnate lo arroja a una fuente ante la perplejidad del detective. Oppenheimer le explica cómo se despilfarra allí el dinero para que salgan bien las cuentas: «En este negocio, si ahorras cincuenta centavos, te cuesta cinco dólares de contabilidad» (Chandler, 2012: 803). Además del derroche escandaloso, otra de las peculiaridades de esta industria, según el mismo personaje, es la cantidad de sexo que lo invade: «Demasiado sexo [...]. Está muy bien en su momento y en su lugar, pero aquí lo tenemos a carretadas. Chapoteamos en él. Estamos hasta el cuello. Acaba siendo como el papel matamoscas» (Chandler, 2012: 802). 
El entramado del cine americano se organiza a nivel sectorial de acuerdo con unas reglas propias, y sus bienes gananciales, con sus altibajos, no dependen de una fórmula matemática exacta equiparable a la de otras empresas. El todopoderoso Oppenheimer —según Phillips (2000: 124), modelado a partir de Y. Frank Freeman, vicepresidente a cargo de las producciones de estudio en la época en que Chandler trabajó para la Paramount - afirma: «El cine es el único negocio del mundo en el que se pueden cometer todos los errores posibles, y aun así ganar dinero» (Chandler, 2012: 803).

Pocos antes, cuando Marlowe intenta localizar a la actriz Mavis Weld en el momento en que estaba filmando una película, le pregunta al vigilante de seguridad:

- [...] ¿Este cristal es a pruebas de balas?

-Pues claro. ¿Por qué?

- Por pura curiosidad [...]. Nunca he sabido de nadie que intentara entrar a tiros en la industria del cine (Chandler, 2012: 801).

Una chica sonriente que lo escuchaba mete baza en el asunto: «—Ay, amigo, si bastara con pegar tiros...» (Chandler, 2012: 801).

La astucia y la violencia como estrategias para lograr el éxito parecen ser aceptables para algunos y algunas. Y los embrollos que van creando y que los aproximan al submundo de la mafia neutralizan las aptitudes actorales o el factor suerte que les habría abierto las puertas del estudio de cine. Ello permite entender los comentarios peyorativos que se lanzan contra los actores. Enfadado con la Weld, después de dos encuentros desafortunados, Marlowe le espeta sin contemplaciones:

todo me hizo pensar que a lo mejor estaba metida en uno de esos escándalos de Hollywood que significan el fin de una carrera. Pero no está metida en ningún lío. Se mantiene en primer plano bajo los focos, soltando todos los viejos clichés que ha utilizado en esas vulgares películas de serie B en las que actúa si a eso se le puede llamar actuar (Chandler, 2012: 768).

Cuando no expresa su desprecio por las actrices y los actores, los cataloga de seres irreales, evanescentes, intangibles. Por mucho que le atraigan eróticamente las estrellas, para él no son más que personas de transitoria corporalidad. Al preguntarle Dolores Gonzales a Marlowe si está enamorado de Mavis, este le responde:

Podría sentarme a su lado en la oscuridad y hacer manitas, pero ¿durante cuánto tiempo? Enseguida saldría volando hacia una nube de glamour, vestidos caros, frivolidad, irrealidad y sexo con sordina. Dejaría de ser una persona de carne y hueso. Solo sería una voz en una banda sonora, un rostro en una pantalla. Yo quiero algo más que eso (Chandler, 899).

Es llamativo que esta novela se configure como una de las pocas de la serie marloweiana en que nuestro detective entra en una sala de cine y describe como un espectador sin demasiado entusiasmo lo que objetivamente ve reflejado en la pantalla. Y no es casual también que una de las imágenes que divisa sea la de la mujer del caso que lo acapara, Ma- 
vis Weld. La crítica que hace de la película está en consonancia con la pobre opinión que le merecía a Chandler la mayoría de los filmes comerciales que se hacían en Hollywood:

Me metí en un cine y, naturalmente, tenían que poner una película de Mavis Weld. Uno de esos engendros de superlujo en los que todo el mundo sonríe demasiado y habla demasiado y es consciente de ello. Las mujeres se pasaban todo el tiempo subiendo por una larga escalinata curva para cambiarse de ropa, y los hombres no hacían más que sacar cigarrillos con sus iniciales de pitilleras carísimas y encender mecheros igualmente caros en las narices de los demás. Los camareros estaban hechos unos cachas, de tanto llevar bandejas con bebidas y una piscina del tamaño del lago Hurón, aunque mucho más cuidada.

El protagonista era un tipo simpático con un montón de encanto, parte del cual se le estaba poniendo ya un poco amarillo por los bordes. La chica era una morena de mal genio, ojos despreciativos y un par de primeros planos tan mal tomados que se la veía perfectamente luchar a brazo partido con sus cuarenta y cinco años. Mavis Weld era la segunda chica y actuaba muy cohibida. Estaba bien, pero podría haber estado diez veces mejor. Claro que si hubiera actuado diez veces mejor, habrían cortado la mitad de sus escenas para proteger a la estrella. Era como caminar en la cuerda floja. Aunque, pensándolo bien, a partir de ahora ya no iba a tener que andar por la cuerda floja, sino por una cuerda de piano, muy alta y sin ninguna red debajo (Chandler, 2012: 722).

Otra actriz llamada Dolores Gonzales, de origen mexicano y presunta amiga de la Weld, alberga sentimientos de avaricia que perturban su paz interior y emponzoñan su relación con los demás, lo cual la empuja fatídicamente por senderos peligrosos, llegando a cometer varios asesinatos. Los móviles de casi todos estos sucesos, con los que se cuestiona la legitimidad de la amistad sincera y se subvierten las convenciones legislativas y morales, son dos: a) la pasión amorosa o sexual, y b) el detonante económico, uno de los principales motores de las sociedades neoliberales capitalistas. En la novela negra, así como en la vida cotidiana de Los Ángeles y, mucho más en un Hollywood que parece estar zarandeado por tantos sobresaltos existenciales como los que se evidencian en las películas de policías y criminales, las cuestiones del espíritu, el amor, las preocupaciones por el bien colectivo y por la solidaridad con los más débiles apenas hallan cabida. Lo único que ondea como una bandera gigante es el individualismo y la lucha por la propiedad privada, además del deseo de sacar adelante cualquier proyecto capaz de generar pingües beneficios pecuniarios.

Pero, en caso de que las artimañas con propósitos lucrativos o el enfermizo antojo sentimental por un hombre o una mujer no sean las causas de las infracciones, es la persistencia de un viejo rencor por no haber alcanzado la fortuna esperada o por no gozar de la reputación profesional de la que alguien se considera merecedor lo que acciona los hilos de la trama. Unida a esta frustración, reverbera también la imposibilidad para asimilar un presente de oprobio, de decadencia y de estrechez después de haber ascendido meteóricamente hasta la cima.

De modo similar al lascivo Bellem o al alcohólico Hammett, que solo exploró el componente narrativo hollywoodense en dos relatos ajenos a la modalidad realista del género 
policiaco $^{20}$, Chandler conoció en primera persona la dinámica por la que se regía el cine de su país, lo mismo que atestigua algunas de las miserias que se cocían de puertas adentro. Es sabido que con Hollywood mantuvo siempre una relación de amor/odio: de amor por el dinero que le reportaba su trabajo como escritor de guiones y por la cálida compañía de las secretarias y de las chicas del estudio; de odio por los extenuantes desencuentros con productores y directores con los que casi nunca se ponía de acuerdo acerca del estilo que debía imprimir a los textos que redactaba para que se filmaran o sobre las adaptaciones al cine de sus propias novelas. En un artículo de 1945, «Writers in Hollywood $»^{21}$, se lamenta de lo mal pagados que estaba la mayoría de los guionistas, aunque reconoce que muchos de los que cobraban un salario digno carecían de las facultades creativas necesarias que les permitirían ganarse la vida en otro sitio. Asimismo, denuncia el aburrimiento que le provoca una industria más pendiente de los resultados en taquilla que de la producción de verdaderas obras de arte: «una interminable contienda entre egos chabacanos, algunos de ellos poderosos, casi todos vociferantes y casi ninguno capaz de hacer algo más creativo que robarle el crédito a otro y promocionarse a sí mismo» (Chandler, 2013: 372). En medio de esos tejemanejes, los guionistas se veían privados de libertad para escribir lo que quisieran y cómo quisieran, ya que los productores lo supervisaban todo ${ }^{22}$. Debido a los numerosos filtros por los que pasaban los guiones, la idea original se veía desvirtuada. Atados de pies y manos, sin ningún poder de decisión y sin obtener algún reconocimiento por su trabajo, los guionistas de Hollywood eran meros títeres en manos de los directivos de los estudios. En «Ten Percent of Your Life», un artículo publicado por primera vez en The Atlantic Monthly (febrero de 1952), carga las tintas contra los agentes literarios tachándolos de individuos sin ética, acostumbrados a manejar un capital considerable, vulgarmente ostentosos y derrochadores: «Va bien vestido y conduce un Cadillac... o alguien lo conduce por él. Posee una mansión en Beverly Hills o Bel-Air. Se sabe que tiene un yate» (Chandler, 2013: 433). Detrás de sus poses encantadoras se agazapa un ser frío y calculador que solo piensa en términos monetarios:

Es un traficante de talento, pero casi nunca respeta ni comprende el talento como tal. Lo único que le interesa es su valor en el mercado [...]. Ronda por los estudios, los restaurantes y los clubs nocturnos, con las orejas estiradas a la caza de chismes y los ojos siempre buscando incansables una cara nueva o importante (Chandler, 2013: 434).

${ }^{20}$ Nos referimos a «On the Way» (1932) sobre un guionista (Kipper) que pierde su trabajo a la vez que su novia consigue su primer papel importante, y al relato satírico «This Little Pig» (1934), que trata de un dramaturgo mercenario que, por dinero, abandona la redacción de una obra de teatro para colaborar en el guion de una película.

21 En Atlantic Monthly (noviembre, 1945).

${ }^{22}$ Esta situación no parece haber mejorado en la actualidad. El agente Eddy Jelko, narrador de Death by Hollywood (2001), una novela Steven Bochco de 2001, expone lo mismo: «me encantan los guionistas porque no creo que haya nada más terrible en el mundo entero que quedarse mirando una página en blanco y ahondar en uno mismo en busca de la inspiración que hace falta para poner los dedos sobre el teclado y sacar algo de la nada, a sabiendas de que cuando acabes, es probable que algún idiota de traje, con todo un arsenal de opiniones y ni pizca de talento, se cague encima del guion» (2004: 42). 
Desde este prisma, da igual las aptitudes literarias que se tengan, ya que, en caso de poseer alguna valiosa, los responsables de los estudios trataban por todos los medios de aniquilarla, con el consiguiente perjuicio para la calidad del producto que terminará filmándose en el plató; de ahí que sentencie en una carta dirigida a George Harmon Coxe (9 de abril de 1939) que «Hollywood es veneno para cualquier escritor, una tumba para el talento» (Chandler, 2013: 29). Una opinión que no mejorará con los años, como se puede verificar en otro artículo escrito en 1948 para Screen Writer que no llegó a publicarse — «A Qualified Farewell»— y en el que Chandler se despacha a gusto: «el uso creativo del talento, que es la base imprescindible de la industria del cine, es algo que los que mandan no entienden en absoluto; de lo contrario, hace tiempo que habrían procurado crear las circunstancias para que pueda florecer» (Chandler, 2013: 407).

En otro ensayo que vio la luz en Atlantic Monthly, «Oscar Night in Hollywood» ${ }^{23}$, se desacraliza la tradicional ceremonia de entrega de los premios de la Academia que se venía celebrando desde 1929. En él declara que, a pesar de que gran parte de las películas rodadas en Hollywood tenían un nulo valor artístico, y pese a la cuestionable fiabilidad de los criterios utilizados por los académicos para conceder galardones (por lo general, la valía de la película se medía más por su éxito que por sus cualidades intrínsecas), se resiste a negarle todo mérito al cine en términos globales: «El cine no es solo un arte, sino que es el único arte completamente nuevo que ha evolucionado en este planeta de cientos de años. Es el único arte en el que los de nuestra generación tenemos alguna posibilidad de destacar, y mucho» (Chandler, 2013: 387). Que se le califique como un entretenimiento de masas no es motivo para menospreciarlo sin más, porque la tragedia griega fue un entretenimiento de masas entre los antiguos atenienses, como lo fue también el drama isabelino para los londinenses de los siglos XVI y XVII. Además, el cine ofrece una ventaja de la que carece la pintura, la música, la arquitectura, la escultura o la literatura, más allá de las herramientas que utiliza: dada su novedad, no estaba tan condicionado aún, al menos a finales de los años 40, que es cuando escribe Chandler, por el peso de la tradición. En otras palabras, es un arte joven y, como tal, su tradición estaba aún inventándose.

A pesar de la tibieza de este juicio, siempre que trae a colación la actualidad de Hollywood, suele ser hiel lo que supuran sus escritos. En este sentido, creemos que, más que en los artículos publicados en la prensa de los años 40, es en la intimidad de la carta personal donde el escritor se explaya a sus anchas:

nunca se encontrará talento suficiente en Hollywood como para hacer un décimo de sus películas con un mínimo de calidad. Admito que se hacen demasiadas; seguirán haciéndose o los cines se cerrarán. Enormes intereses creados y la vida de incontables miles de personas están en juego. Admito también que el noventa por ciento de las películas de Hollywood no valdría la pena hacerlas; digo que el noventa por ciento de los libros y las obras teatrales y los cuentos a partir de los que se hacen no vale la pena verlos o leerlos, según las mismas normas (Chandler, 2013: 64$)^{24}$.

23 En Atlantic Monthly (marzo, 1948).

${ }^{24}$ Esta carta, fechada el 18 de diciembre de 1944, está dirigida a Charles Morton. 
Por último, en uno de los artículos citados con anterioridad, «The Qualified Farewell», subraya que el mejorable valor de la mayor parte de las películas hechas en Hollywood se debe al miedo de los y las guionistas a enfrentarse a las exigencias de productores superficiales que, descontentos con su labor, pudiesen no renovarles sus contratos (Chandler, 2013: 403).

En concordancia con estos pronunciamientos respecto al quehacer cinematográfico, y a contrapelo de la dictadura que tuvo que sufrir durante los cinco años en que trabajó en la Meca del Cine, los relatos breves y las narraciones extensas de Chandler consiguen crear un espacio climático que da cobijo a la inclemencia, al doloroso imperativo del más fuerte y a la obsesión de poder omnímodo que se aposenta en una sociedad como la de los Estados Unidos regida por la cultura de la doble moral, la pérdida de principios éticos y donde la megalomanía, el materialismo, el triunfo de las bajas pasiones, la brutalidad y el «sálvese quien pueda» se imponen a expensas de la nobleza de sentimientos, el altruismo o el compromiso político-social con los desfavorecidos. Eso nos lleva a recordar que el cineasta ruso Sergei M. Eisenstein escribió en 1944 que «el capitalismo encuentra su reflejo más agudo y expresivo en el cine norteamericano» (1995: 182), razón por la cual él, que provenía del marxismo-leninismo, no pudo encontrar un hueco en él. The Little Sister y otras obras de Chandler parecen darle la razón en el plano de la ficción al aserto emitido por el director moscovita. En The Little Sister un macilento Marlowe, sin un centavo en el bolsillo, se tropieza con agentes publicitarios, representantes artísticos, gerentes de estudios, actrices de un erotismo casi gélido arracimados en una selva en la que solo sobreviven unos pocos, ya que la mayoría es engullida por un remolino de supercompetitividad, un caos de dependencias psicológicas y de intrascendencia existencial. Las consecuencias que para los sujetos más disconformes con este sistema de productividad tiene esa cohorte de fútiles rencores y de vidas torcidas por la ambición son, como mínimo, el ostracismo, pues, en cuanto reaccionan de modo contestatario, son apartados de la circulación o fracasan en sus proyectos, si no perecen antes a manos de sus adversarios.

La narrativa noir norteamericana cartografía, veladamente o sin medias tintas, el irresistible abismo hacia el que los inadaptados, los parias de la sociedad, los ingenuos y la llamada «gente decente» terminan precipitándose. Ralph Carston y Mona Matthews, protagonistas de la novela de McCoy I Should Have Stayed Home son inequívocos ejemplos de unas personalidades vulnerables que ellos disfrazan con arrebatos de infantil ira que no los conducen a mejorar su futuro. A diferencia de estos, un amigo de ambos llamado Johnny Hill representa el polo opuesto: la especie del depredador, del que sale a flote inteligentemente merced a un talentoso poder camaleónico que le permite adaptarse a las circunstancias más hostiles, e incluso beneficiarse de ellas, sin remordimientos de conciencia. Expublicista de la Universal y de Excelsior, Hill es uno de los personajes secundarios que en I Should Have Stayed Home simboliza el prototipo del triunfador nato. Sus contadas intervenciones en la ficción de McCoy vehiculan, en contraposición a lo que consideran Carston y Matthews, el lado prosaico de un punto de vista que muchos harán suyo; es él quien aporta con sus propios razonamientos uno de los juicios inapelables sobre los soeces ambientes que lo rodean: «Una cosa que he aprendido en Hollywood es que es un juego que no se puede jugar según el reglamento. Una patada en los órganos genitales es su idea del 
juego limpio» (McCoy, 1980: 149). Al principio aparece como un muchacho que, pese a su edad, ha asimilado ya esa dura lección, solo que aún no tiene en su haber las fichas necesarias para jugar la partida sin correr riesgos. Pero más adelante, en las últimas páginas del relato, su situación ha dado un giro drástico: después de conocer a la rica señora Smithers, cree haber dado con la clave para agenciarse el desahogo económico que andaba buscando, aun cuando para ello tenga que renunciar a sus inquietudes artísticas y vencer la repugnancia que posiblemente le han de provocar los escarceos eróticos con una mujer que le dobla la edad, encaprichada sexualmente de hombres más jóvenes. Entonces Johnny, con sangre fría, declara sin dudar: «al final tengo las armas para atacar a un montón de bastardos a quienes desprecio. Lo único que cuenta en esta ciudad es la pasta. Y ahora que la tengo, volveré la otra mejilla a todas las personas que no me gustan, una mejilla de oro. Ya les enseñaré» (McCoy, 1980: 148-49).

El sueño de un progreso sin límites — transformado para algunos en pesadilla- es una de las prioridades en la agenda del bon vivant Johnny Hill que diseña McCoy, como también en la del Sammy Glick trazado brillantemente por Budd Schulberg en su novela de 1941 What Makes Sammy Run?, que, de chico de los recados, crecido en los suburbios judíos del Bronx, se convierte en magnate de Hollywood. La amalgama de objetivos que converge en Los Ángeles y en sus cercanías hacia finales de los años 30 y durante los 40, espacios colmados de malevolencia, impudicia y sordidez — en afinidad con las preferencias de los maestros de la literatura noir, sin excluir las versiones desenfadadas del español Pgarcía protagonizadas por Gay Flower, menos complacientes, sin duda, que las también humorísticas de Kaminsky, padre de otro detective icónico, en este caso admirador confeso de las estrellas del cine, Toby Peters-, halla en la instrumentalización del cinematógrafo y en la discutible formalización de sus banales productos para contentar a «la facción más estúpida del público» (Chandler, 2013: 407) un pretexto idóneo que le permite evaluar la degradación moral, las angustias más íntimas y las miserias de la gente poderosa, muy en la línea de esta especie literaria moderna.

Para dar peso a la verosimilitud de las acciones se recurre en algunos casos a ambientes reconocibles en el mundo real. En The Long Goodbye (1953), Marlowe cena en el Musso's con Terry Lennox, un hombre de aspecto miserable, borracho, hambriento, al que no le sonríe la suerte ${ }^{25}$; pero más adelante, cuanto retoma su relación con su millonaria esposa, Len-

25 En The Way Some People Die (1951), de MacDonald, Archer come en este mismo restaurante. El Musso \& Frank Grill, que también aparece en algunas novelas clásicas como The Day of the Locust (1939) de Nathanael West y What Makes Sammy Run? de Schulberg, es un restaurante localizado en el Hollywood Boulevard e inaugurado en 1919. Recibe su nombre de sus propietarios originarios, Joseph Musso y Frank Toulet, aunque hasta 1923 tenía otro nombre: François. Se le considera «la génesis de Hollywood». Desde su fundación, ha sido crucial en la vida social de la industria cinematográfica de Los Ángeles. De hecho, el restaurante mantuvo un cuarto trasero separado para su clientela del cine, que comprendía no solo a guionistas, sino también a actores, productores y directores. En 1927 fue vendido a Joseph Carissimi y John Mosso, experimentando una ampliación en 1936. La sala grande del lado este del restaurante, abierta en 1955, todavía es llamada «el Salón Nuevo». Durante la década de los 30 Musso's se erigió en el centro de la vida cultural hollywoodense. Stanley Rose tenía una librería que estaba justo al lado, y muchos de los escritores de la ficción hard-boiled que a él le gustaban y cuyos libros exponía en el cuarto trasero del local pasaban innumerables horas en el Musso \& Frank; por ejemplo, Cain, Schulberg, John Fante (que frecuentó el restaurante con el famoso periodista e historiador Carey 
nox y el detective toman copas repetidas veces en el Victor's, otro restaurante vinculado a Hollywood que se ha mantenido abierto hasta 2015.

Junto a los establecimientos de copas y comida, los platós son otros de esos lugares cruciales que se tornan inquietantes, donde las balas vuelan sobre las cabezas de los intérpretes, incluso en pleno rodaje; donde florecientes artistas de musicales pueden ver sus carreras truncadas, así como sus vidas, a manos de resentidas amistades más bellas que ellas; donde conocidos cómicos se angustian ante el reclamo de una deuda que juran no haber contraído y que, por lo tanto, se resisten a pagar y donde actores especialistas en roles de vampiros reciben anónimas amenazas escritas con algo parecido a sangre. Esto es lo que sucede, por ejemplo, en las novelas de Kaminsky ${ }^{26}$ y en muchos de los relatos de Bellem. No digamos ya el escándalo que supone el que sean los mismos astros los que inventan un falso delito para obtener así algún rédito. Justamente esto es lo que maquina el actor en horas bajas John Vidaury en el relato «Pick-Up on Noon Street», de Chandler ${ }^{27}$, quien, para recuperar la popularidad perdida, sobre todo tras el batacazo de su última película, idea un sagaz plan del que se arrepiente cuando ya es demasiado tarde. En este cuento la estrella llega a matar de un disparo a un hombre al querer suspender el falso chantaje que presuntamente le hacía el propietario de un club nocturno, en complot con el actor. Vidaury había hecho circular el rumor de que lo habían amenazado con destrozarle el rostro con un ácido si no accedía a pagar en metálico las cantidades que le solicitaban. Pero todo formaba parte de un bulo orquestado con fines meramente publicitarios. Al final, en cuanto empiezan a amontonarse los primeros cadáveres, esa mentira acabará estallándole en su cara por culpa de un buscavidas llamado Pete Anglich, en principio al margen de toda esta tramoya, que pone al descubierto el montaje gansteril del elegante intérprete colocándolo en un serio aprieto.

En la narrativa policiaca no podía faltar la imagen deletérea de la femme fatale, una misógina ficción generada por el pánico masculino de artistas y escritores como Chandler. Representación ebria de antifeminismo, la mujer fatal, que se gesta en la literatura y el arte románticos, simbolistas y decadentistas del siglo XIX, cobra nueva vida un siglo más tarde tras su paso al séptimo arte y a la narrativa negra engendrada en las revistas pulp, destinadas a un público masculino y rebosantes de machismo. En The Little Sister Dolores Gonza-

\footnotetext{
McWilliams), Chandler y West. Otros asiduos de las letras fueron Saroyan, Hammett, Erskine Caldwell, Dorothy Parker, Faulkner, Fitzgerald, Elliot Paul y Donald Ogden Stewart. En la década de los 40 el restaurante estaba ya tan firmemente identificado con la escena literaria de Los Ángeles que aspirantes a escritores como Charles Bukowski beberían allí en un esfuerzo consciente por emular a sus eminentes antecesores (véase la recreación que hace en su novela Hollywood, donde, acompañado de su esposa Sarah y el director Jon Pinchot, Henry Chinaski, alter ego del escritor, toma una copa tras otra y entabla conversación con productores de cine). Hasta el día de hoy el restaurante ha conservado su carácter original, que incluye altos techos, paneles de madera oscuros y cabinas rojas. Sus camareros se visten con los mismos abrigos rojos que llevan usando durante décadas. Debido a su estatus como lugar icónico, el Musso \& Frank ha aparecido en algunos filmes notables como Ed Wood (1994) de Tim Burton, Ocean's Eleven (2001) de Stephen Sodenbergh y Greenberg (2010) de Noah Baumbach, así como en muchos otros ambientados en esa época.

26 Véanse, por ejemplo, Bullet for a Star (1977), Murder on the Yellow Brick Road (1977), You Bet your Life (1978) o Never Cross a Vampire (1980).

27 Originariamente el cuento se titulaba «Noon Street Nemesis» (Detective Fiction Weekly, 30 de mayo de 1936), pero al publicarlo en la colección The Simple Art of Murder el autor le cambió el título.
} 
les, morena de armas tomar, provocativa y vanidosa, se ajusta a ese cliché: «No me habría sorprendido que me aplicara una pistola a los riñones. Se había situado de manera que prácticamente tuve que apartarle los pechos para poder pasar por la puerta. Su olor era como la imagen del Taj Mahal a la luz de la luna» (Chandler, 2012: 763).

Ese olor embriagador que despide esa mujer de pechos prominentes, caderas insinuantes, melena oscura y unas pinzas doradas con las que sostiene un largo cigarrillo, la convierten en prototipo kitsch de mantis religiosa que engatusa al desprevenido macho para después «comérselo» o despedazarlo de un bocado. Dotada de un estratégico equipamiento físico que derrocha erotismo latino y peligrosidad a partes iguales, la fémina busca atrapar en su tela de araña al detective incauto: «Sus labios quemaban como el hielo. Su lengua se apretaba contra mis dientes. Sus ojos eran inmensos y negros y se les veía el blanco» (Chandler, 2012: 765).

Rozando lo autoparódico, la descripción no escatima medios que engrandecen la condición vampírica de la muchacha. En un arrebato de sinceridad, reconoce ella: «El sexo es una red que utilizo para pescar tontos. Algunos de esos tontos son útiles y generosos. De vez en cuando, cae uno peligroso» (Chandler, 2012: 829). Siempre va vestida de negro «porque soy hermosa, malvada... y estoy perdida» (Chandler, 2012: 853). Marlowe la define como «exquisita», pero también «tenebrosa, letal» (Chandler, 2012: 899) y como alguien «[t]otalmente fuera de las leyes morales de este mundo y de cualquier otro que yo pudiera imaginar» (Chandler, 2012: 899). Al remarcar el fogonazo hipnótico que irradia la hermosura sensual e irresistible de la chica — «Esbelta, encantadora y sonriente. Rezumando sexo» (Chandler, 2012: 899)—, además de la aureola letal que deja tras sí, el personaje de Gonzales se vuelve casi una caricatura del modelo de la hembra devoradora de hombres que se pavonea en este tipo de novelas, así como en el cine negro de mediados del siglo pasado.

La industria de Hollywood degrada a los que orbitan en torno a ese satélite, hasta tal punto de que los vuelve en malvados sin escrúpulos avasallados por nefastas aspiraciones de poder y de fama, si es que no estaban ya pervertidos antes de recalar en ese escurridizo ámbito de trabajo.

Con todo, aun cuando la mala fama y las conductas cuestionables persigan a los protagonistas del cine, sería justo recordar lo que dice el empresario Sherry Ballou, postrado en un diván mientras una chica rubia le aplica comprensas en la cabeza ${ }^{28}$. En su opinión, la disipación en los hábitos de los actores es indispensable para que estos puedan meterse en la piel de los papeles que encarnan en la pantalla, muchos de los cuales se corresponden con personajes de vida irregular, poco edificante, e incluso maquiavélica: «Si los actores no lle-

${ }^{28} \mathrm{Su}$ estampa es casi una parodia de los agentes de cine, siempre aquejados de alguna dolencia (jaquecas, úlceras, sudoración excesiva...) por efecto del estrés o de las preocupaciones constantes. La figura de Ballou se completa con otros aditamentos: el ir de un lado a otro de su despacho «con andares de Piccadilly y un bastoncito en la mano», una costumbre que, según este productor, se lo transmitió otro colega suyo de la Metro-GoldwynMayer (Chandler, 2012: 797). Tales tics se volverán característicos de los que ocupan cargos de responsabilidad en ese oficio. 
varan una vida intensa y bastante desordenada, si no se dejaran arrastrar tanto por sus emociones... bueno, no serían capaces de coger esas emociones al vuelo e imprimirlas en unos metros de celuloide o proyectarlas a través de las candilejas» (Chandler, 2012: 798).

Esta visión —en el caso de Ballou comprensiva, pero no tanto según el criterio de otros personajes o del mismo narrador- explica tal vez la extensa hilera de mafiosos, timadores, maleantes, contrabandistas, embusteros, mujeres problemáticas y outsiders que tiñen los angostos callejones de las ficciones de Chandler y de otros representantes de la literatura policiaca como Daly, Bellem, Hammett o MacDonald y, en particular, en lo que al universo hollywoodense atañe, de la literatura criminal ambientada en los Estados Unidos de América, el país que viera nacer esta modalidad con tan larga descendencia en la narrativa y en el cine contemporáneos. La representación ficcional enmarcada en claroscuros, truculenta, asfixiante y a veces cromáticamente expresionista de estas creaciones sostenidas sobre los pilares del homicidio y su consiguiente castigo por parte de la ley se refuerza con el uso de leitmotivs y de otros elementos estereotipados, como las atmósferas sombrías, ruinosas, presididas por la agresividad, que condimentan unos argumentos complejos mediante la técnica del suspense, elevadas dosis de tensión y un ritmo narrativo trepidante que va ganando pulso a cada página, o como la pintura de un elenco de mujeres de aviesas intenciones que encandilan con sus vertiginosas caderas a cuanto hombre se les cruza en su camino. Ficciones ahogadas en litros de güisqui, disueltas en las volutas del humo que asciende por habitáculos cerrados y claustrofóbicos, cosidas a balazos con un viejo Colt o una pistola Luger, cuartillas escritas con los hilillos de sangre que gotean sobre las alfombras de las ostentosas casas de los ricos, los garitos más cochambrosos o el asfalto recalentado de los nocturnos bulevares de California. Son estos componentes, entre otros, los que se trasladan, desde la década de los 30 en adelante, al cine americano de serie B, a la par que al relato literario, el cual, como cabe especular, toma prestadas del séptimo arte estas mismas coordenadas en un ejercicio de retroalimentación.

La impronta de la estética fílmica en la escritura policiaca es posible rastrearla en frases como la siguiente de The Big Sleep, de 1939, donde se describe al chantajista Joe Brody: «Su voz era la voz exageradamente despreocupada de los tipos duros de las películas. El cine los ha hecho a todos así» (Chandler, 2012: 65). Con esta mención a un medio de diversión popular que conjuga imagen y sonido se infiere una vaga idea del modo de hablar del personaje; para imaginarlo solo necesitamos asociar lo que dice el texto con su representación icónica en la pantalla; pero al mismo tiempo se da a entender que gánsteres de cine como Humphrey Bogart o George Raft sirvieron de modelos a mafiosos reales, tanto en los gestos y en las formas de comunicarse como en su vestimenta y en otras costumbres.

Los caracteres de las obras clásicas del género, con la salvedad de los sujetos a los que se les encomienda dar con la solución del conflicto, es decir, los detectives, periodistas o abogados, suelen ser perdedores o delincuentes, o ambas cosas a la vez. A los mencionados hasta aquí, agreguemos a Larry Batzel, típico antihéroe, de aparición fugaz en el relato chandleriano titulado «The Curtain» ${ }^{29}$. El narrador autodiegético dice haberlo visto siempre

${ }^{29}$ Publicado en Black Mask (septiembre, 1936). 
en estado de embriaguez, llevando una vida inestable en la que alternan etapas de ostentación con otras en que vive acosado por las deudas. Y su final no puede ser menos apoteósico. Tras probar suerte en el cine — sin éxito alguno-, se inmiscuye en operaciones cada vez más ilícitas y, poco después de iniciarse la narración, muere en plena calle acribillado por unos matones que se dan a la fuga en un sedán azul. Infelices son también esas chicas ingenuas en busca de una oportunidad que en los relatos de Bellem o en las novelas de McCoy o de Donald Stuart no logran ver cumplidas sus expectativas de hacerse con un nombre dentro del negocio cinematográfico, ya que, o bien son explotadas como esclavas sexuales, o bien acceden a compartir el lecho con algún magnate bajo falsas promesas de obtener un insignificante papel en una película olvidable, o bien fallecen asesinadas. O los jóvenes ilusionados con los fulgores de las marquesinas pero cada día más desesperados al ver que el tren que los transportaría a la gloria pasa de largo por sus vidas, de manera que terminarán con sus huesos en la sala de un tribunal de justicia, suicidándose en una lúgubre celda o, en el mejor de los casos, desposándose con un vulgar candidato o candidata que los/les procura una existencia anodina, tal vez con las necesidades básicas cubiertas, pero sin un átomo de emoción.

\section{CONCLUSIÓN}

Si damos crédito al modo en que Hollywood cristaliza en la narrativa hard-boiled de los años 30, 40 y 50, durante los que vivió Chandler, obtenemos una imagen diametralmente contraria al deslumbrante colorido de las alfombras rojas, a las montañas de dólares acumuladas a fuerza de proyectos inteligentemente planificados y al desarrollo de un arte desinteresado, deviniendo, en cambio, un quebradizo zoo de cristal en el que descuella el combate feroz de sus moradores, especie de animales en celo, víboras corroídas por las traiciones, las mezquindades, reino vano de la utopía, umbral de una felicidad inalcanzable y, muy frecuentemente, espacio para la muerte, como muestra el devenir de personajes como Sonny Steelgrave, Orrin Quest, Mavis Weld, Dolores Gonzales, Billy Fortescue, Alex Morny, Rhonda Farr, Derek Walden, John Vidaury o Larry Batzer, presas de un presente o pasado oprobioso y de un futuro siniestro; o las cavilaciones, amargas, escépticas, reflexivas, del cínico narrador protagonista o de personajes como Sherry Ballou o Jules Oppenheimer en The Little Sister, que apuntan en esta misma dirección. Hurgar en las hediondas cloacas hollywoodenses, en la sangre que se solidifica debajo de las capas de glamur que lo cubren, presupone una vía de acceso a un festín destinado siempre a desentumecer los míseros organismos de un parasitario y vergonzoso sector de la población americana que la narrativa negra, en sus distintos eslabones, escudriña una y otra vez con insaciable morbo. En tales formaciones narrativas exentas de idealizado simbolismo, pletóricas de desaliento, estupor y animadversión, se entiende la ira de Marlowe cuando, cansado de remover tanta mugre, exclama: «A la mierda las estrellas de cine» (Chandler, 2012: 770), sentencia puesta en boca de un ente de ficción para coloquializar el ambiguo resentimiento que sentía el propio escritor hacia el mundo del cine. 


\section{REFERENCIAS BIBLIOGRÁFICAS}

AdLER, TIM (2008): Hollywood y la mafia: Los sangrientos gánsters de la historia y su influencia en el mundo del cine (trad. de J. Planas), Barcelona, Robinbook.

Bochco, Steven (2004): Muerte en Hollywood (trad. de E. Iriarte Goñi), Barcelona, Ediciones B.

Cerqueiro, Diana (2010): «Sobre la novela policiaca», Ángulo Recto, II, 1, párrs. 1-94 <http://revistas.ucm.es/index.php/ANRE/article/view/ANRE1010120007A/6104> [Consulta: 25 oct. 2018].

Chandler, Raymond (1996): El simple arte de matar (ed. bilingüe; introd. y notas de M. González de la Aleja Barberán, trad. de J. Á. González López y A. González Ausín), León, Universidad de León.

Chandler, Raymond (2010): Todos los cuentos (pról. de L. Silva, trad. de F. G. Corugedo), Barcelona, RBA.

Chandler, Raymond (2012): Todo Marlowe (trad. de J. L. López Muñoz, J. M. Ibeas Delgado, C. Criado, F. Páez de la Cadena, A. Herrera y P. Giralt Gorina), $8^{a}$ ed., Barcelona, RBA.

Chandler, RAYMOnd (2013): A mis mejores amigos no los he visto nunca: Cartas y ensayos selectos (trad. de C. Aira y J. M. Ibeas), Barcelona, Random House Mondadori.

Christensen, Diana L. (2014): «The Hollywood Dream: A Nightmare in American Literature» (tesis de máster), California State University.

Clark, Al (1996): Raymond Chandler in Hollywood, Los Angeles, Silman-James.

Edington, K. (1995): «The Hollywood Novel: American Dream, Apocalyptic Vision», Literature/Film Quarterly, XXIII, 1, pp. 63-69.

Eisenstein, Sergei M. (1995): «Dickens, Griffith y el cine en la actualidad», en La forma del cine (ed. de J. Leyda, trad. de M. L. Puga), $3^{\text {a }}$ ed., México, D. F., Siglo XXI, pp. 181-234.

Fitzgerald, F. Scott (2014): El último magnate (pról. de E. Wilson, trad., epíl y notas de D. Ortega), Barcelona, Navona.

Gabler, Neal (2015): Un imperio propio: Cómo los judios inventaron Hollywood (pról. de R. Gubern, introd. y ed. de D. Moldes, trad. de V. Fernández Castro, M. Fernández Valls, M. Gámez Márquez y R. Ibáñez de la Torre), [Aguadulce (Almería)], Confluencias.

Hecht, Ben (1946): ;Los actores son un asco! (trad. de E. de Guzmán), [Barcelona], Lauro.

Luhr, William (1991): Raymond Chandler and Film, $2^{\mathrm{a}}$ ed. Tallahassee, Florida State University.

MacDonald, Ross (2010): El blanco móvil (trad. de L. La Fuente), Barcelona, RBA.

MacShane, Frank (2017): La vida de Raymond Chandler (trad. de P. Giralt), Barcelona, Alrevés.

McCoy, Horace (1980): Luces de Hollywood (trad. de P. Giralt Gorina), 2a ed., Barcelona, Bruguera, 1980.

McNeil, Legs y Osborne, Jennifer (con Pavia, Peter) (2008): El otro Hollywood: Una historia oral y sin censurar de la industria del cine porno (trad. de Ó. Palmer Yánez), Madrid, Es Pop.

Moss, Robert F., ed. (2003): Raymond Chandler: A Literary Reference, New York, Carroll \& Graf.

Pendo, Stephen (1976): Raymond Chandler on Screen: His Novels into Film, Metuchen, Scarecrow.

Phillips, Gene D. (2000): Creatures of Darkness: Raymond Chandler, Detective Fiction, and Film Noir, Lexington, The University Press of Kentucky.

Rhodes, Chip (2008): Politics, Desire and the Hollywood Novel, Iowa City, University of Iowa Press. 